\title{
Seismic Imaging of Seabed Morphology Offshore Niger Delta
}

\author{
Babangida Jibrin \\ Department of Geology and Mining, Ibrahim Badamasi Babangida University, Nigeria
}

Copyright $(2015$ Horizon Research Publishing All rights reserved.

\begin{abstract}
D seismic data have been used to describe the seabed morphology offshore Niger Delta in the Gulf of Guinea. The seabed morphology is characterized by bathymetric ridges and grooves related to gravity-driven thrusting and folding in the Niger Delta compressional domain, numerous canyons, and fluid venting structures with morphologies similar to pockmarks. The pockmarks are found predominantly parallel to canyon margins, along the axis of bathymetric grooves and ridges and in places related to discontinuities on the seafloor. The densest concentration of pockmarks along canyon margins is probably due to active seepage of hydrocarbon fluids from shallow and or deep subsurface reservoirs. The large scale occurrence of pockmarks is a strong evidence of fluid migration processes and perhaps the existence of an active petroleum system in the area.
\end{abstract}

Keywords Offshore, Niger Delta, Seismic Data, Seabed, Morphology

\section{Introduction}

In the last decade, remotely operated vehicles (ROVs) have been used to acquire seafloor data for investigating hydrocarbon seepage along continental margins. Hydrocarbon seepages are of great significance to explorationists because they are often direct indicators of the existence of petroleum systems. These processes have previously been documented in a wide variety of geological settings using highly specialized underwater vehicles, cruise ships and remote satellite data $[1,2,3,4,5]$. In recent times, advances in offshore seismic data acquisition and processing and the availability of good quality marine $3 \mathrm{D}$ seismic data with improved resolution imply that seismically-mapped seabed bathymetry can be used to characterize seabed morphology using standard seismic reflection data during routine seismic interpretation at sufficiently high resolutions.
In this paper, seismic evidences of hydrocarbon seepage are mapped using a seabed bathymetry generated from a dense grid of 3D seismic data acquired in an area of overlapping maritime boundary between Nigeria and Sao Tome and Principe (Figure 1). With increasing oil and gas exploration activities in the deep-water Niger Delta, this paper demonstrates that conventional 3D seismic data can provide invaluable data for petroleum system analysis in offshore Niger Delta.

\section{Materials and Methods}

The 3D data cover an area of $3000 \mathrm{~km}^{2}$ in water depths ranging from $\sim 1300 \mathrm{~m}$ to $\sim 2700 \mathrm{~m}$ in the Niger Delta compressional structural domain (Figure 1). The data have inline and crossline spacing of 25 and $12.5 \mathrm{~m}$ respectively. The recording interval is $9 \mathrm{~s}$ with a $4 \mathrm{~ms}$ sampling rate. The data are displayed with a reverse polarity and have been zero-phased migrated with vertical scale in seconds (s) two-way travel time. Spectral analysis shows that the dominant frequency varies from 18 to $28 \mathrm{~Hz}$ between 3.5 and $6.0 \mathrm{~s}$ two-way travel time. A frequency of $\sim 20 \mathrm{~Hz}$ that appears to be the strongest in the amplitude spectrum plot was used to calculate the maximum vertical resolution of the data.

The maximum vertical resolution is $\sim 25 \mathrm{~m}$ at shallower sections but deteriorates in the deeper sections. Vertical resolution was computed using an interval velocity versus depth plot of the offshore Niger Delta [6]. The seafloor vertical resolution is $\sim 8 \mathrm{~m}(46 \mathrm{~Hz})$ assuming a water velocity of $1500 \mathrm{~ms}^{-1}$. The seabed horizon is a strong trough that was largely mapped by auto-tracking based on visual amplitude character recognition. However, the horizon was manually picked where the reflection continuity is truncated by complex reflection events especially at the base of canyons and crests of bathymetric ridges. Finally, the dense grid of horizon picks was gridded to produce a model of the surface. 


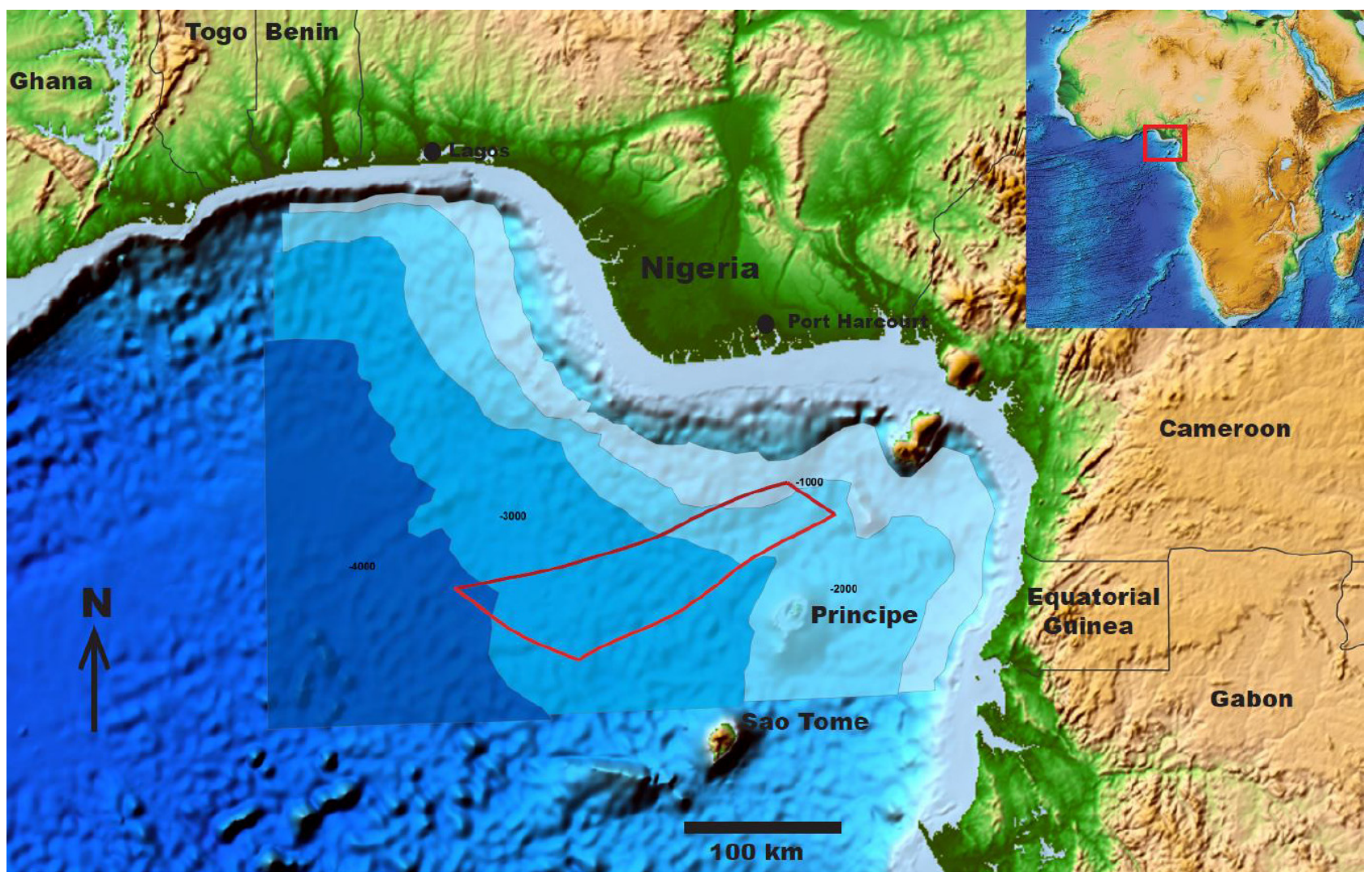

Figure 1. Bathymetric and shaded relief map of the Gulf of Guinea showing the study area.

\section{Results and Discussion}

Water depths ranges from $\sim 1340 \mathrm{~m}$ in the north-east to $\sim 2660 \mathrm{~m}$ in the south-west (Figure 2). Seabed relief is generally gentle in the northeast but becomes undulating toward the southeast, northwest and southwest. Two distinct geomorphic domains have been identified in the eastern and western parts of the seabed. An arcuate-shaped bathymetric ridge that traverses the seabed in an $\mathrm{EW}$ orientation is the reference for this division. The ridge is typically incised by numerous N-S trending canyons. Across the ridge in the east, seabed morphology is characterized by NE-SW trending ridges and grooves that in places are contain pockmark craters.

Canyons in the area have gentle edges upslope but become erosive downslope (basinward). Geomorphic feature of the seabed consists of numerous canyons that traverse the area in a NE - SW direction and cutting across the arcuate bathymetric ridge. This pattern of interaction implies that the channels post-date the ridge or that the incision of the channels kept pace with the growth of the ridge (Westbrook, personal communications). In deep-water settings in passive continental margins, these canyons are the primary means for sediment transportation from shelf deltas to the deep-water to form slope channels and fans $[7,8]$.

Closely linked to the canyons in the eastern part of the ridge are numerous seafloor depressions that line up along the canyon margins. These structures possess morphologies similar to pockmarks [9]. Pockmarks occur wherever fluid flow is focused and escape is from low-permeability, fine-grained surficial sediments [10]. The pockmarks in the area are also found within bathymetric ridges and grooves and also randomly distributed. Pockmark morphologies in the area are typical of "unit pockmarks". These morphologies represent the most recent and active local fluid seepage locations on the seabed [11]. Pockmarks that are inactive tend to have a smoother morphology than those that leak hydrocarbon fluids [12].

In the area, pockmark density is related to bathymetry. In addition to the canyon margin, the densest concentration of pockmarks is along a region of sharp change in bathymetry (white dashed line in Figure 3). In general, the density decreases with increasing bathymetry. Some of the pockmarks are probably active i.e. still venting fluids, while some are inactive (green and red arrows in Figure 4 respectively). Pockmark density along the canyon margin decreases toward the ocean, perhaps implying the presence of shallow reservoir quality units. It is also possible that the conduits for fluid migration are lacking with increasing value of bathymetry or the lack of good quality reservoir units. The concentration of pockmarks along canyon margins is most likely due to vertical fluid migration from shallow and or deep seated reservoirs. Similar pockmark belts mapped on the lower slope of the Congo Basin are interpreted to indicate shallow buried turbidites $[1,12]$. Random distribution of pockmarks may probably be due to variation in factors controlling fluid expulsion from the sediments to the seabed. 


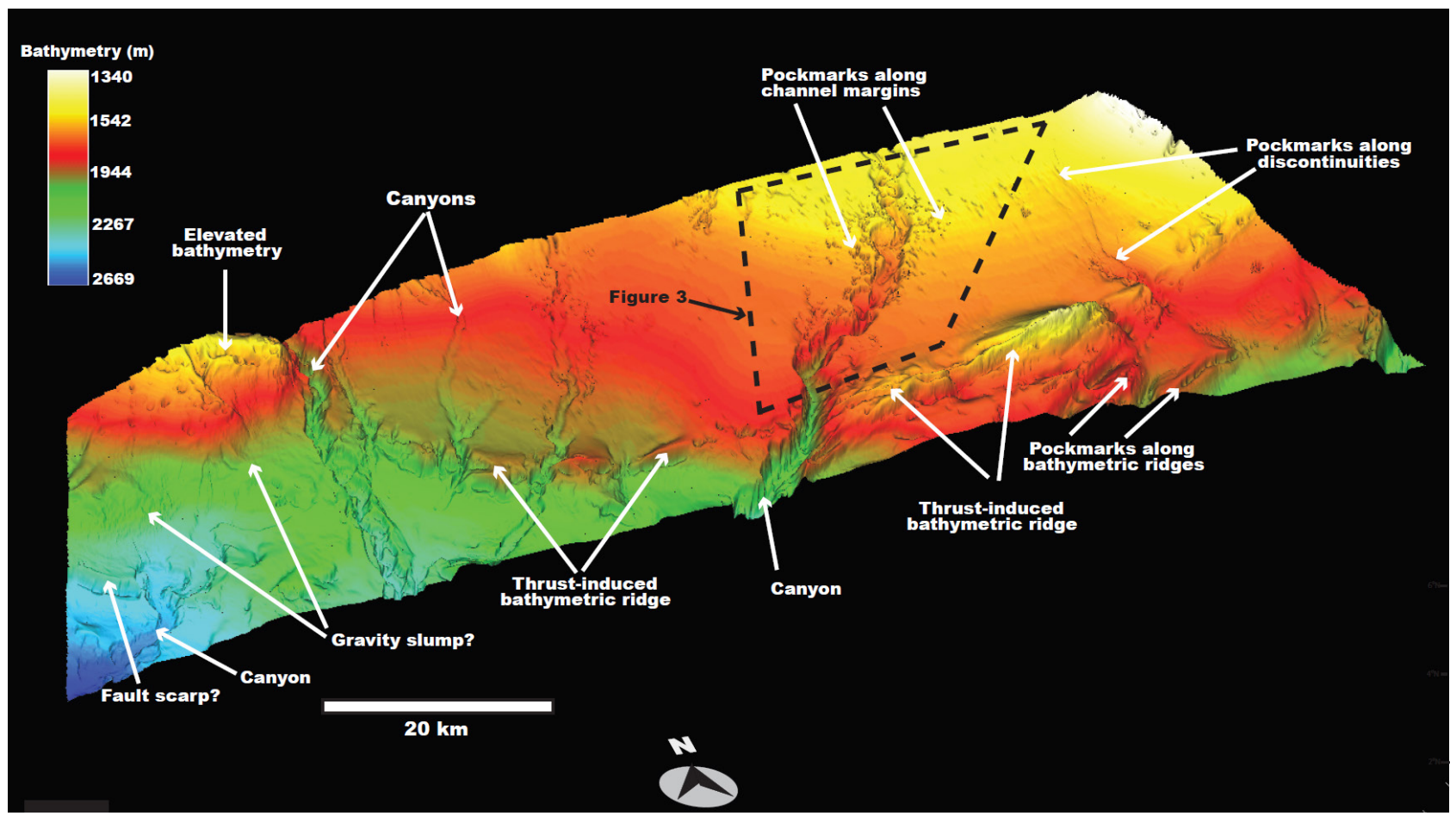

Figure 2. Perspective view of the seabed horizon showing present-day morphology in the study area. Note the large concentration of fluid venting features in the areas highlighted (Dashed). Illumination and view is from the northeast. Vertical exaggeration is $\sim \mathrm{x} 3$.

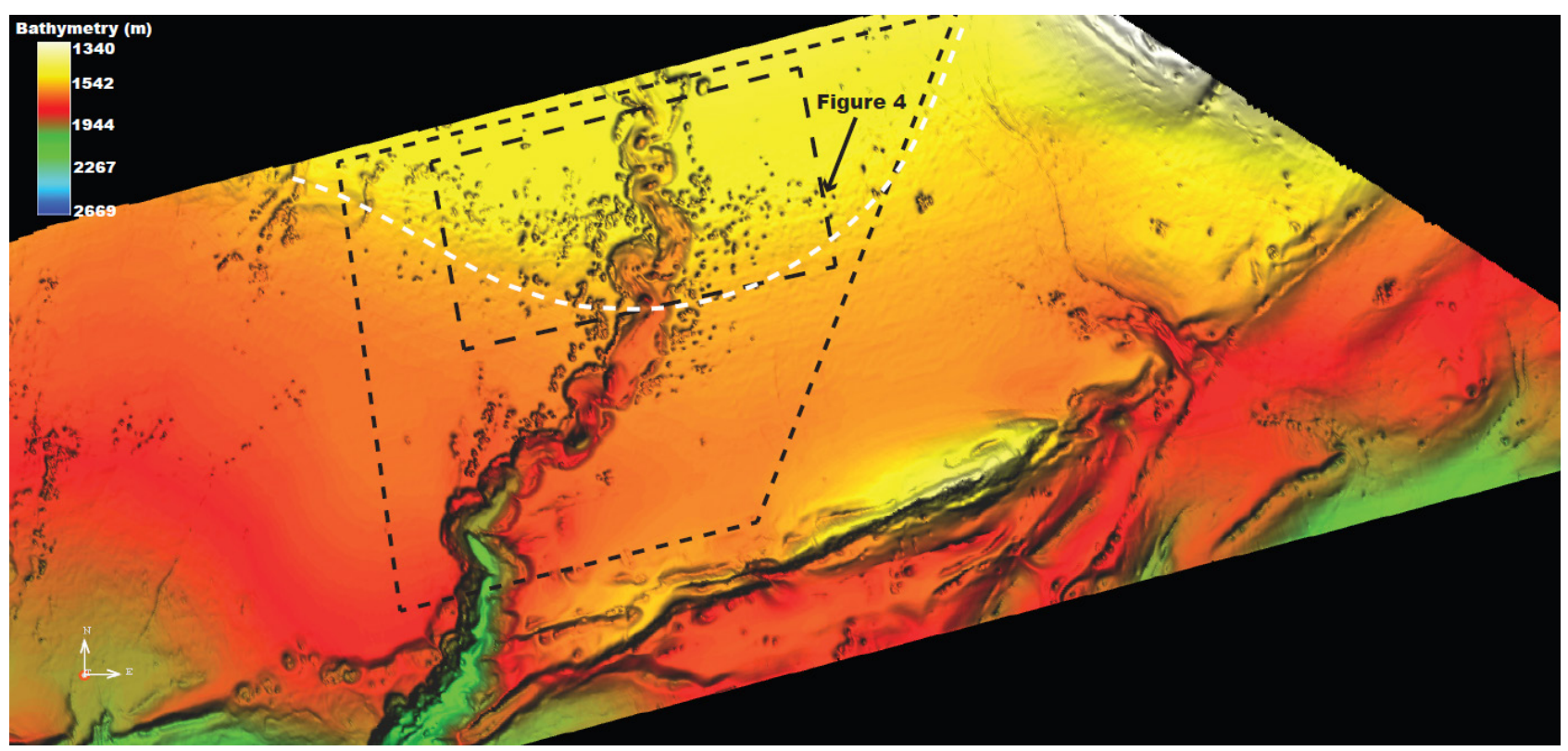

Figure 3. Depth map of the seabed showing unit pockmarks aligned parallel to the axis of a major N-S trending canyon 


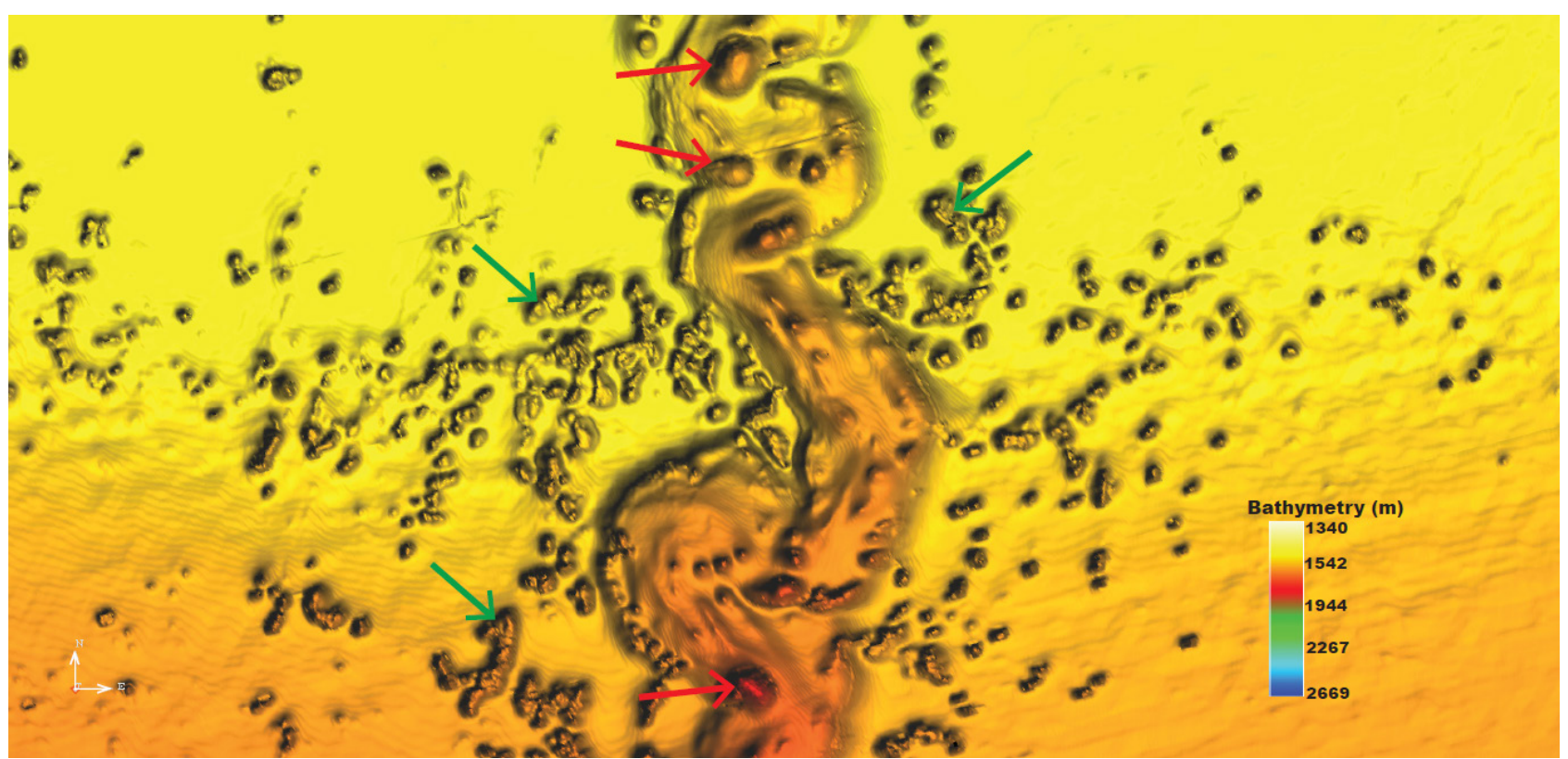

Figure 4. Close-up view of pockmark distribution and density in the area. The red arrows shows large isolated pockmarks within the canyon exhibiting smooth rounded crater geometry, while the green arrows show connected smaller unit pockmarks with uneven morphology.

\section{Conclusions}

Detailed mapping of seabed bathymetry reveals a large-scale distribution of fluid venting structures interpreted as unit pockmarks. The dense concentration of these structures parallel to canyon margin may be related to expulsion of hydrocarbon fluids from shallow and or deeper sources. The distribution of the structures is also related to bathymetry, toward the ocean, the density is lowest, but highest in the upper reaches of the canyon. Analysis of pockmark morphology shows that some pockmarks are still active and seeping fluids to the seabed, whereas others are inactive. These observations support the existence of an active petroleum system in area between Nigeria and Sao Tome and Principe.

\section{Acknowledgements}

The author is grateful to Petroleum Geo-Services (PGS) for providing the 3D seismic data and permission to publish the data. Seismic Micro-Technology (SMT) provided Kingdom seismic interpretation software.

\section{REFERENCES}

[1] M. Hovland, A. Judd. Seabed pockmarks and seepages, Impact in geology, biology and the marine environment, Graham and Trotman, London, 1988.

[2] M. Hovland, J. Gallagher, M. Clennell, K. Lekvam. Gas hydrate and free gas volumes in marine sediments: Examples from the Niger Delta front: Marine and Petroleum Geology, Vol. 14, No. 3, 245 - 255, 1997.
[3] A. Gay, M. Lopez, C. M. Séranne. Geological controls on focused fluid flow associated with seafloor seeps in the Lower Congo Basin, Marine Geology, Vol. 244, 68-92, 2007.

[4] D. Connolly, R. Garcia. Tracking hydrocarbon seepage on Argentina's Neuquén basin, World Oil, 101-104, 2012.

[5] H.D. Dave, S. Mazumder, J.K. Samal, K.K.S. Pangtey, D.S. Mitra. Mapping hydrocarbon seepages using satellite SAR data in Eastern Offshore - Essential input in oil exploration, $9^{\text {th }}$ Biennial International Conference and Exposition on Petroleum Geophysics, 2012.

[6] P.R. Cobbold, B.J. Clark, H. Loseth. Structural consequences of fluid overpressures and seepage forces in the outer thrust belt of the Niger Delta, Petroleum Geoscience, Vol. 15, No. 1, 3-15, 2009.

[7] Z. Jobe, D. Lowe, S. Uchytil, Two fundamentally different types of submarine canyons; Modern and ancient examples from the continental margin of Equatorial Guinea, West Africa, Presented at AAPG Annual Convention and Exhibition, 2011.

[8] M. Deptuck, Z. Sylvester, C. O'Byrne. Pleistocene seascape evolution above a "simple" stepped slope - Western Niger Delta, SEPM Special Publication, Vol. 99, 199 - 222, 2012.

[9] M. Hovland, J. Gallagher, M. Clennell, K. Lekvam. Gas hydrate and free gas volumes in marine sediments: Examples from the Niger Delta front: Marine and Petroleum Geology, Vol. 14, No. 3, 245 - 255, 1997.

[10] M. Hovland, A. Judd. Seabed pockmarks and seepages, Impact in geology, biology and the marine environment, Graham and Trotman, London, 1988.

[11] M. Hovland, R. Heggland, M.H., De Vries, T.I. Tjelta. Unit-pockmarks and their potential significance for predicting fluid flow, Marine and Petroleum Geology, Vol. 27, No. 6, 1190-1199, 2010.

[12] G.A. Villaflor. Multibeam bathymetry and backscatter data 
analysis of pockmarks at Vestnesa Ridge off NW-Svalbard, Master's thesis, The Arctic University of Norway, 2014.

[13] A. Gay, M. Lopez, P. Cochonoat, N. Sultan, E. Cauquik, F.
Bigaud. Sinuous pockmark belt as an indicator of a shallow buried turbiditic channel on the lower slopes of the Congo basin, West African margin, Geological Society of London Special Publication Vol. 216, 2003. 